\title{
Responses of freshwater molluses to environmental factors in Southern Brazil wetlands
}

\author{
Maltchik, L. ${ }^{\mathrm{a}}$, Stenert, $C .^{\mathrm{a}}$, Kotzian, $C B .{ }^{\mathrm{b}}{ }^{\text {and Pereira, } D .}{ }^{\mathrm{c}}$ \\ ${ }^{a}$ Laboratório de Ecologia e Conservação de Ecossistemas Aquáticos, \\ Universidade do Vale do Rio dos Sinos - UNISINOS, \\ Av. Unisinos, 950, CEP 93022-000, São Leopoldo, RS, Brazil \\ ${ }^{\text {b}}$ Departamento de Biologia, Universidade Federal de Santa Maria - UFSM, \\ CEP 97105-900, Santa Maria, RS, Brazil \\ 'Laboratório de Malacologia, Museu de Ciências e Tecnologia, \\ Pontifícia Universidade Católica do Rio Grande do Sul - PUCRS, \\ Av. Ipiranga, 6681, CEP 90619-900, Porto Alegre, RS, Brazil \\ *e-mail:maltchik@unisinos.br
}

Received January 20, 2009 - Accepted April 13, 2009 - Distributed August 31, 2010

(With 2 figures)

\begin{abstract}
Freshwater molluscs play an important role in aquatic ecosystems, providing food for many fish species and vertebrates. Investigations on factors that determine mollusc species richness and distribution in wetland systems are scarce in the Neotropical region. The main goal of this study was to determine how much variation in mollusc richness and composition is explained by area, hydroperiod, altitude, water conductivity, and dominant aquatic vegetation. This survey was performed in an extensive area of a Neotropical region $\left(280,000 \mathrm{~km}^{2}\right.$ in southern Brazil), with a large number of wetland systems (111) and covering a wide gradient of altitude and wetland surface area. The mollusc richness was positively associated with wetland area and negatively associated with altitude. The richness and composition of the freshwater molluscs were similar between permanent and intermittent wetlands and it did not differ significantly between aquatic bed and emergent wetlands. The first three axes of CCA explained $16.2 \%$ of the total variation in the composition of the freshwater mollusc observed. The variation in the composition had a correlation with wetland area, altitude and water conductivity. Our results showed that the wetlands are important habitats for molluscs in southern Brazil, and that the richness and the composition of molluscs were associated with area, altitude, water conductivity and dominant vegetation.
\end{abstract}

Keywords: wetland area, altitude, hydroperiod, aquatic vegetation, neotropical region.

\section{Respostas de moluscos límnicos a fatores ambientais em áreas úmidas do sul do Brasil}

\section{Resumo}

Moluscos límnicos desempenham um papel importante em ecossistemas aquáticos, fornecendo alimento para diversos peixes e vertebrados. Investigações sobre os fatores que determinam a riqueza e a distribuição das espécies de moluscos em áreas úmidas são escassos na região neotropical. O principal objetivo deste estudo foi determinar a variação na riqueza e na composição de moluscos em função da área, hidroperíodo, altitude, condutividade da água e tipo de vegetação aquática dominante. Este estudo foi desenvolvido em uma extensa área Neotropical ( 280.000 km² no sul do Brasil), com um elevado número de áreas úmidas (111) e compreendeu um amplo gradiente de altitude e tamanho de áreas úmidas. A riqueza de moluscos foi positivamente relacionada com o tamanho da área úmida e negativamente relacionada com a altitude. A riqueza e a composição de moluscos foram similares entre áreas úmidas permanentes e intermitentes e não diferiram significativamente entre áreas úmidas herbáceas e emergentes. Os três primeiros eixos da CCA explicaram $16,2 \%$ da variação na composição de moluscos. A variação na composição foi correlacionada com a área, altitude e condutividade da água. Nossos resultados mostraram que as áreas úmidas são ecossistemas importantes para os moluscos límnicos no sul do Brasil e que a riqueza e a composição de moluscos estiveram relacionadas à área, altitude, condutividade da água e tipo de vegetação aquática dominante.

Palavras-chave: áreas úmidas, altitude, hidroperíodo, vegetação aquática, região neotropical. 


\section{Introduction}

Wetlands are important sites for biological conservation because they support a rich biodiversity and present high productivity (Mitsch and Gosselink, 2000). However, biodiversity in wetlands is being reduced in most of the world by agricultural, urban and industrial development (Shine and Klemm, 1999). Almost half of the world's wetlands have disappeared over the last century due to agricultural and urban development (Shine and Klemm, 1999). The rapid degradation of wetlands and the insufficient status of scientific knowledge on patterns of the species richness bring the urgent need for ecological studies to provide scientific support to biodiversity management and conservation programs.

One of the main hydrological characteristics of South America is the existence of large wetlands (Neiff, 2001). Approximately $50 \%$ of the inventoried wetlands in South America are located in Brazil (Naranjo, 1995). Conservative data indicate that approximately $90 \%$ of the wetlands in southern Brazil disappeared in the last century due to agricultural expansion, especially rice and soy plantations (Gomes and Magalhães, 2004). In this sense, the understanding of species composition and richness patterns in fragmented and natural wetlands is a priority for biodiversity conservation strategies and land/ water management in southern Brazil.

The macroinvertebrate community is an important trophic level in wetland systems, providing food for several wildlife species. The macroinvertebrate structure in wetlands has been associated with area and habitat heterogeneity (Oertli et al., 2002; Batzer et al., 2004; Panatta et al., 2006; Studinski and Grubbs, 2007; Stenert et al., 2008); hydroperiod (Tarr et al., 2005; Whiles and Goldowitz, 2005; Stenert and Maltchik, 2007); altitude (Oertli et al., 2002; Jacobsen, 2004); water chemistry (Heino, 2000; Batzer et al., 2004), and water depth and temperature (Zimmer et al., 2000; Hall et al., 2004; Tarr et al., 2005; Studinski and Grubbs, 2007). However, most of these surveys were developed in the North Hemisphere and Australia. In the Neotropical region, Stenert and Maltchik (2007) demonstrated that area and hydroperiod are important predictors of macroinvertebrate richness and composition in 72 wetlands distributed in southern Brazil and the occurrence of molluscs was observed in more than $65 \%$ of studied wetlands.

Freshwater molluscs play an important role in aquatic ecosystems, providing food for many fish species (McMahon and Bogan, 2001; Garcia et al., 2006; Fagundes et al., 2008) and vertebrates (Cummins and Bogan, 2006). A total of 373 native species of freshwater molluscs were registered in Brazil, 117 attributed to bivalves and 256 to gastropods, but these numbers are underestimated and may represent only $50 \%$ of the total malacofauna (Simone, 2006). Additionally, about nine alien species have been recorded in Brazilian inland waters (Simone, 2006), but accurate estimates of the number of mollusc species in southern Brazil are unknown.
The environmental factors that determine the mollusc richness and distribution in inland waters have been investigated. Water hardness, conductivity, $\mathrm{pH}$ altitude, substrates (plants), food resources (plants) and biotic interactions have been reported as important environmental predictors of molluscs (Dillon, 2000; Brown, 2001; Gérard, 2001; McMahon and Bogan, 2001; Heino and Muotka, 2006; Sturm, 2007; Horsák et al., 2007). The species-area relationship was not always consistent for wetland molluscs. While the richness of snails tended to increase with wetland area (Lassen, 1975; Aho, 1978; Brönmark, 1985), this relationship was not significant for Sphaeriidae (Oertli et al., 2002). Investigations on factors that determine mollusc species richness and distribution in wetland systems are scarce in the Neotropical region.

The main goal of this study was to determine how much variation in mollusc richness and composition is explained by area, hydroperiod, altitude, water conductivity, and dominant aquatic vegetation. This survey was performed in an extensive area of a Neotropical region $\left(\sim 280,000 \mathrm{~km}^{2}\right.$ in southern Brazil), with a large number of wetland systems (111) and covering a wide gradient of altitude and wetland surface area.

\section{Material and Methods}

\subsection{Study area}

The state of Rio Grande do Sul is located in the south of Brazil and has an area of 282,184 $\mathrm{km}^{2}$ (Figure 1). The Moist Subtropical Mid-Latitude Climate prevails in this region. The annual precipitation varies between $1,200-1,800 \mathrm{~mm}$, and it is relatively well distributed over the year, without the existence of a dry period ( $\mathrm{Cf}$ Köpen's climate classification). The mean temperature varies between 15 and $18{ }^{\circ} \mathrm{C}$. The minimum tempera-

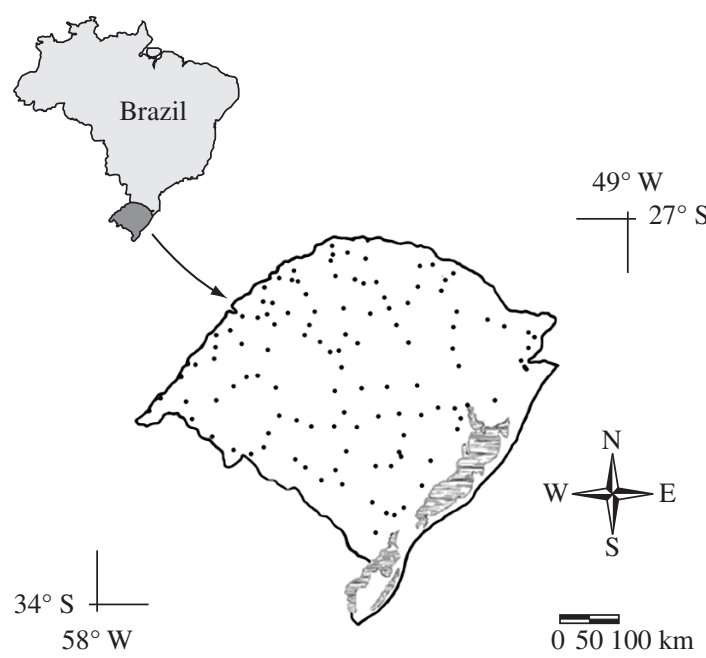

Figure 1. Location of study area (state of Rio Grande do Sul, Brazil) with the position of all studied sites. 
ture is lower than $10{ }^{\circ} \mathrm{C}$ in the winter, and the maximum temperature is higher than $32{ }^{\circ} \mathrm{C}$ in the summer (RADAMBRASIL, 1986).

Rio Grande do Sul has approximately 3,441 wetlands, with a total inundation area of approximately $30,332 \mathrm{~km}^{2}$ (Maltchik, 2003), distributed in five geomorphologic provinces: Coastal Plain, Central Depression, Crystalline Shield, Highlands and Pampas (Hausman, 1995). The vegetation is characterised by small fragments of forest, with temperate and tropical grassland areas. The forested areas are represented by temperate summer-green and mixed ever-green deciduous forests, and temperate mountainous coniferous forest. The grasslands are represented by savanna, steppe, and pioneering formations (RADAMBRASIL, 1986; Rambo, 2000).

A total of 111 wetlands were sampled in the state of Rio Grande do Sul based on three criteria: 1) area no larger than $10 \mathrm{ha}$; 2) macrophyte presence, and 3) fairly even distribution of the wetlands across the state of Rio Grande do Sul (Figure 1). Sampling was performed initially in the eastern portion of the state of Rio Grande do Sul, and then moved towards the western portion. Each wetland was sampled once from March to October 2002, always during the period with surface water. The studied wetlands were classified in permanent ( 84 wetlands) and intermittent (27 wetlands). Permanent wetlands retain water for the entire hydrological cycle, whereas intermittent wetlands eventually dry up, retaining water for at least four months of the year (Maltchik et al., 2004). All wetlands presented vegetation cover higher than $30 \%$ of the total wetland surface. While permanent wetlands were represented mainly by aquatic bed (submerged and floating plant species - 45 wetlands) and emergent (erect herbaceous vegetation - 29 wetlands) vegetations, intermittent wetlands showed predominance of emergent vegetation ( 24 wetlands).

The wetland area was measured in the field. The wetland boundaries were determined based on 1) visual observations of the watermarks, drift line and/or owners' information, and 2) vegetation indicators (e.g., plants with morphological, physiological or reproductive adaptations to prolonged saturation/inundation, and the proportion between aquatic and terrestrial species in the plant community). The wetlands location and altitude were determined using a GPS receiver (model GPS III Plus, Garmin).

\subsection{Data collection}

Two surface water samples were collected in the littoral zone of each wetland using polyethylene bottles $(500 \mathrm{~mL})$. All samples were placed on ice in dark containers and taken to the laboratory, and immediately filtered upon return to the laboratory (Whatman ${ }^{\circledR} \mathrm{GF} / \mathrm{F}$ glass fiber filters, pore size $0.7 \mu \mathrm{m}$ ). Analysis of water samples did not exceed 3-4 days after field collection. Measurement of water conductivity $\left(\mu \mathrm{S} . \mathrm{cm}^{-1}\right)$ was performed with the methodology provided by APHA (1989).
Mollusc collections were carried out using a kick net (D-shaped, $30 \mathrm{~cm}$ width, $400 \mu \mathrm{m}$ mesh). Sampling was limited to the littoral zone of wetlands (water depths of less than $50 \mathrm{~cm}$ ), by kicking up the substrate and then sweeping above the disturbed area. The sampling effort was the same for all wetlands, represented by 25 sweeps of $1 \mathrm{~m}$ over the various habitats of the littoral zone (detritus, rooted macrophytes and other dominant vegetation). Sweeps were pooled into one sample per wetland (3.5 L plastic bucket) and preserved in situ with $10 \%$ formaldehyde.

In the laboratory, each sample was washed through a $400 \mu \mathrm{m}$ sieve, and leaves, stems, and other debris were removed. The resulting material was preserved with $80 \%$ ethanol. Individuals were identified at genus and species level (when possible), by using the extensive malacological literature available. Ancylids and sphaeriids were identified only at family level due to the shell preservation condition. Mollusc richness corresponded to the number of taxa (genera or species) collected in each sampled wetland.

\subsection{Data analyses}

The continuous environmental variables considered in the analyses were wetland area, altitude, and water conductivity, and the categorical variables considered in the analyses were wetland hydroperiod (permanent and intermittent) and vegetation cover (aquatic bed and emergent). In order to remove the heteroscedasticity, continuous environmental variables were log transformed.

Correlations among area, altitude and water conductivity were tested using the Pearson's correlation coefficient. Variation of mollusc richness between permanent and intermittent wetlands was quantified through a $t$-test. In permanent wetlands, richness variation between aquatic bed and emergent vegetation was also analysed through a $t$-test. Multiple regressions (GLM) were carried out to ascertain the extent to which wetland area, altitude and water conductivity explained the patterns of mollusc richness in all wetlands and in permanent and intermittent wetlands.

The direct multivariate analysis of the environmental parameters in the composition of freshwater molluscs in the studied wetlands was carried out through Canonical Correspondence Analysis (CCA) (Ter Braak, 1986), using PC-ORD Version 4.2 (McCune and Mefford, 1999), and the significance of the axes generated in the analysis was validated through the Monte Carlo test (using 5,000 iterations) (Ter Braak and Šmilauer, 1998). Environmental variables utilised in the CCA were: wetland area, altitude, water conductivity, and the combination of hydroperiod (permanent and intermittent) and dominant vegetation (aquatic bed, emergent and multi-stratified). Environmental data were centred and normalised. Biological variables were based on the presence and the absence of the mollusc taxa occurring in four or more wetlands. Composition variations between permanent and intermittent wetlands, and among aquatic 
bed, emergent and multi-stratified wetlands were tested through the Multi-Response Permutation Procedures (MRPP). The MRPP is a multivariate analysis which tests differences between two or more groups.

\section{Results}

The range and mean values of wetland area, altitude, and water conductivity in the studied wetlands are shown in Table 1. Wetland altitude was negatively correlated with wetland area $(\mathrm{r}=-0.486, \mathrm{P}<0.001)$ and water conductivity $(r=-0.274, \mathrm{P}=0.004)$. Wetland area was not correlated with water conductivity $(r=0.126$, $\mathrm{P}=0.187$ ).

A total of eight freshwater mollusc families and 10 genera were found in the studied wetlands (Table 2).
Five species of molluscs were identified: Pomacea canaliculata Lamarck, 1801; Biomphalaria tenagophila Orbigny, 1835; Lymnaea columella (Say, 1817); Omalonyx convexus (Martens, 1868) and Eupera klappenbachi Mansur and Veitenheimer-Mendes, 1975. Planorbidae and Sphaeriidae were the families that showed the greatest species richness in the studied wetlands (Table 2). The most frequent mollusc taxa were Biomphalaria $(40.5 \%$ - found in 45 wetlands), Pomacea canaliculata (18.9\% found in 21 wetlands) and Drepanotrema (18\% - found in 20 wetlands). The most frequent taxa were also those with broad geographic distribution. The majority of the genera and species identified were present in less than $10 \%$ of the sampled wetlands. Heleobia and Musculium were found in just a single sampled wetland (Table 2).

Table 1. Ranges and mean of selected environmental variables characterising the studied wetlands in southern Brazil.

\begin{tabular}{|c|c|c|c|c|c|c|}
\hline \multirow{2}{*}{$\begin{array}{c}\text { Environmental } \\
\text { variables }\end{array}$} & \multicolumn{2}{|c|}{ All wetlands } & \multicolumn{2}{|c|}{ Permanent wetlands } & \multicolumn{2}{|c|}{ Intermittent wetlands } \\
\hline & Range & Mean & Range & Mean & Range & Mean \\
\hline Wetland area (ha) & 0.01 to 10 & 1.97 & 0.03 to 10 & 2.25 & 0.01 to 10 & 1.09 \\
\hline Wetland altitude (m) & 1 to 1,058 & 285.72 & 1 to 1,046 & 281.45 & 24 to 1,058 & 299 \\
\hline Water conductivity $\left(\mu \mathrm{S} . \mathrm{cm}^{-1}\right)$ & 16 to 325 & 78.95 & 16 to 292 & 77.36 & 23.20 to 325 & 83.88 \\
\hline
\end{tabular}

Table 2. Taxonomic list of freshwater molluscs and the number of wetlands where each mollusc taxon was found according to hydroperiod and dominant aquatic vegetation (PA = permanent wetlands with aquatic bed vegetation; $\mathrm{PE}=$ permanent wetlands with emergent vegetation; $\mathrm{PM}=$ permanent wetlands with multi-stratified vegetation; IE = intermittent wetlands with emergent vegetation; and IM = intermittent wetlands with multi-stratified vegetation).

\begin{tabular}{|c|c|c|c|c|c|}
\hline \multirow[t]{2}{*}{ Taxons } & \multicolumn{5}{|c|}{ Hydroperiod and vegetation } \\
\hline & PA & PE & $\mathbf{P M}$ & IE & IM \\
\hline \multicolumn{6}{|l|}{ GASTROPODA } \\
\hline Ampullaridae & 5 & - & - & 4 & - \\
\hline Pomacea canaliculata & 5 & 8 & 4 & 3 & 1 \\
\hline \multicolumn{6}{|l|}{ Hydrobiidae } \\
\hline Heleobia & - & 1 & - & - & - \\
\hline \multicolumn{6}{|l|}{ Physidae } \\
\hline Physa & 1 & - & 1 & - & - \\
\hline \multicolumn{6}{|l|}{ Lymnaeidae } \\
\hline Lymnaea columella & - & 3 & - & 2 & - \\
\hline \multicolumn{6}{|l|}{ Planorbidae } \\
\hline Drepanotrema sp. 1 & 7 & 4 & - & 2 & - \\
\hline Drepanotrema sp. 2 & 2 & 1 & 1 & 4 & - \\
\hline Biomphalaria tenagophila & 4 & 7 & - & 3 & - \\
\hline Biomphalaria & 10 & 3 & - & 6 & - \\
\hline Biomphalaria sp. 1 & 1 & 1 & - & 1 & - \\
\hline Biomphalaria sp. 2 & 6 & 3 & 1 & 4 & - \\
\hline Ancylidae & 4 & 1 & 2 & 1 & - \\
\hline \multicolumn{6}{|l|}{ Succineidae } \\
\hline Omalonix convexus & 1 & 3 & - & 1 & - \\
\hline \multicolumn{6}{|l|}{ BIVALVIA } \\
\hline Sphaeriidae & 10 & 9 & 2 & 14 & - \\
\hline Pisidium sp. 1 & 1 & 1 & - & - & - \\
\hline Pisidium sp. 2 & 1 & 1 & - & - & - \\
\hline Eupera klappenbachi & 2 & 1 & - & - & - \\
\hline Eupera & 1 & 1 & - & - & - \\
\hline Musculium & 1 & - & - & - & - \\
\hline
\end{tabular}


Mollusc richness ranged from 0 to 8 per wetland, and it was positively associated with wetland area and negatively associated with altitude $\left(\mathrm{GLM}, \mathrm{R}^{2}=0.103, \mathrm{~F}_{3,107}=\right.$ $4.113, \mathrm{P}=0.008)$. The richness of the freshwater molluscs was similar between permanent and intermittent wetlands $\left(t_{109}=0.770, \mathrm{P}=0.443\right)$, and water conductivity was not associated with mollusc richness $(\mathrm{P}>0.05)$. In relation to dominant aquatic vegetation, the richness did not differ significantly between aquatic bed and emergent wetlands $\left(t_{72}=-0.587, \mathrm{P}=0.559\right)$.

While the mollusc composition was similar between permanent and intermittent wetlands (MRPP, $\mathrm{A}=0.0005$, $\mathrm{P}=0.365$ ), the molluscs composition was different between aquatic bed and the multi-stratified wetlands (MRPP, $\mathrm{A}=0.082, \mathrm{P}=0.002$ ) and between emergent and multi-stratified wetlands (MRPP, $\mathrm{A}=0.049, \mathrm{P}=$ $0.003)$. The first three axes of CCA explained $16.2 \%$ (7.7\% in axis $1,5.4 \%$ in axis 2 , and $3.1 \%$ in axis 3 ) of the total variation in the composition of the freshwater mollusc (Table 3). Wetland area, altitude and permanent wetlands with multi-stratified vegetation were correlated with axis 1 . Water conductivity and permanent wetlands with emergent vegetation were correlated with axis 2 . The Monte-Carlo simulation test (5,000 iterations) showed that the variation in the mollusc composition had a correlation with both variable sets correlated with axes 1 and 2 (Table 3). While Pomacea canaliculata, Pisidium, Eupera and Ancylidae were more frequent in permanent wetlands with larger area and located at lower altitudes, Omalonyx convexus, Lymnaea columella, Drepanotrema and Biomphalaria were observed mainly in wetlands with lower area and located at higher altitudes. Omalonyx convexus, Pisidium and Eupera were more associated with more elevated water conductivity (Figure 2). Omalonyx convexus was also associated with permanent wetlands and emergent vegetation (Figure 2). Ancylidae and Biomphalaria were observed mainly in wetlands with lower water conductivity (Figure 2).

\section{Discussion}

The observed mollusc richness represented the species molluscs usually found in lentic environments of southern Brazil, Argentina and Uruguay. The most frequent taxa (Biomphalaria, Pomacea canaliculata and Drepanotrema) was previously observed in different wetland classes, such as lakes, ponds, streams, backwater rivers, dams and rice fields (Chieffi and Moretti, 1979; Bonetto et al., 1982; Mochida, 1991; Pereira et al., 2000a,b, 2001; Kloos et al., 2004; Agudo-Padrón and Oliveira, 2008). The high frequency of Pomacea canaliculata, Pisidium and Eupera can be attributed to their ability to support variations at water level (Bachmann, 1960; Junk and Robertson, 1997, Kretzschmar and Heckman, 1995). Gundlachia, Omalonyx convexus and Eupera were also observed floating in water in Neotropical wetland systems (Neiff and Neiff, 2006). The scarcity of Heleobia should be investigated, since this genus was commonly associated to aquatic macrophytes in this region (Coimbra et al., 2005). Darrigran (2002) pointed out that the introduction of alien species was responsible for the declining of Heleobia species in Argentina. The absence of the Mycetopodidae (Anodontites e Mycetopoda) and Hyriidae (Diplodon genus) families may be associated to the kind of sampler used, since these individuals are usually observed buried in deep sediment. Mansur and Pereira (2006) observed eight bivalve species in southern Brazil wetlands.

A positive relationship between macroinvertebrate richness and area has been found for specific taxonomic groups of macroinvertebrates (Spencer et al., 1999; Heino, 2000; Oertli et al., 2002; Sanderson et al., 2005; Studinski and Grubbs, 2007). Stenert and Maltchik (2007) showed that area was an important predictor of macroinvertebrate richness and composition in southern Brazil wetlands. Our study showed that the wetland area was positively associated with mollusc richness. However, this relationship is not always consistent,

Table 3. Summary of Canonical Correspondence Analysis (CCA) results, for the 111 wetlands studied in southern Brazil.

\begin{tabular}{lccc}
\hline & \multicolumn{3}{c}{ CCA axes } \\
\cline { 2 - 4 } & $\mathbf{1}$ & $\mathbf{2}$ & $\mathbf{3}$ \\
\hline Eigenvalue & 0.230 & 0.162 & 0.094 \\
Cumulative \% variance of mollusc taxons & 7.7 & 13.0 & 16.2 \\
Pearson correlation: taxa-environment data & 0.650 & 0.567 & 0.458 \\
Inter-set correlation & & -0.143 \\
Wetland altitude & 0.574 & -0.115 \\
Wetland area & -0.286 & -0.178 \\
Permanent and multi-stratified wetlands & -0.327 & -0.036 & 0.280 \\
Water conductivity & 0.053 & -0.479 & 0.073 \\
Permanent and emergent wetlands & 0.112 & -0.284 & -0.006 \\
Monte Carlo test & & 0.004 & 0.014 \\
Eigenvalues (P) & & 0.050 & 0.035 \\
Taxons-environment correlations (P) & 0.061 & 0.051 \\
\hline
\end{tabular}



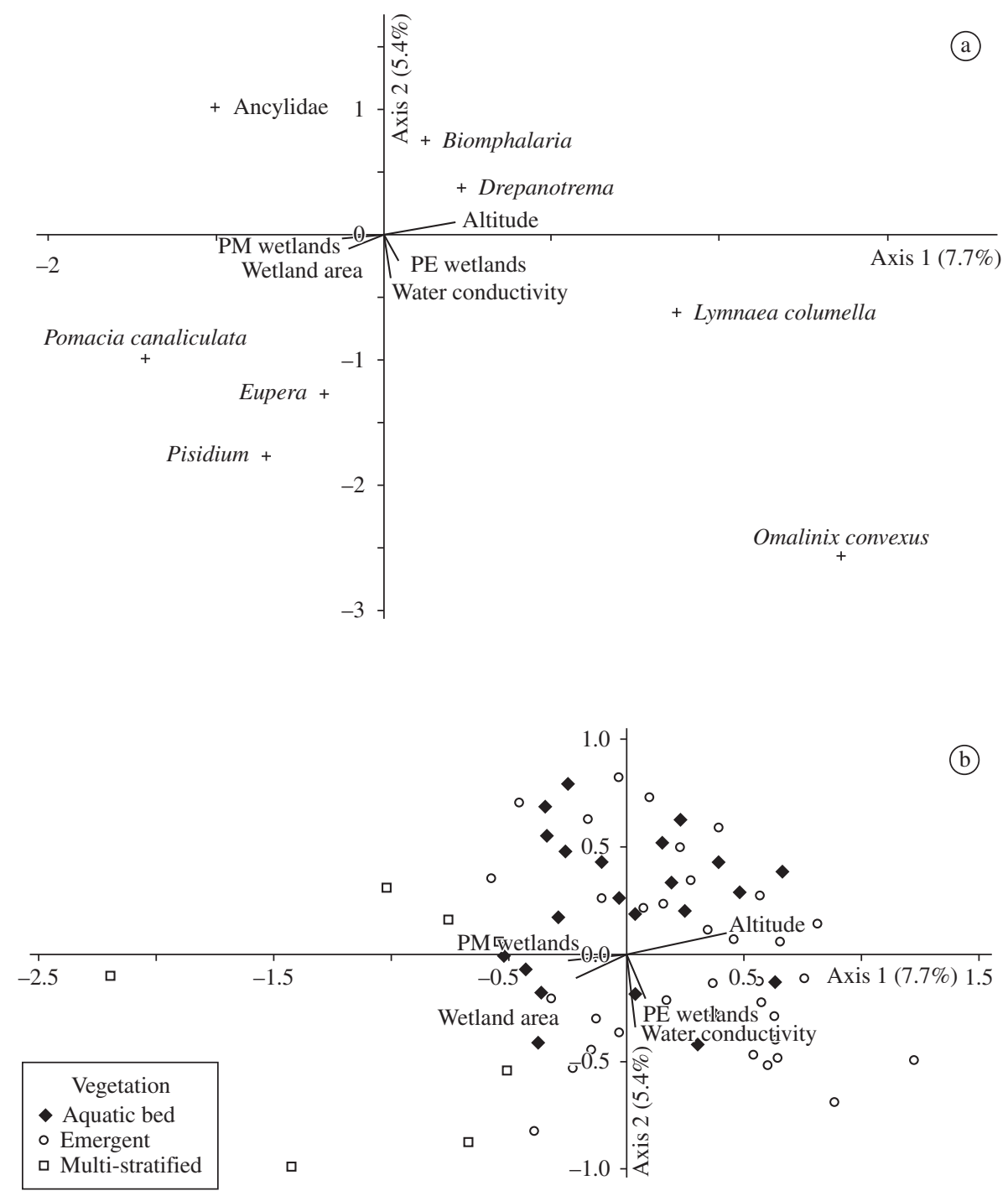

Figure 2. Diagrams of Canonical Correspondence Analysis (CCA) ordination: a) Relationship among mollusc taxa and environmental variables (vectors); and b) Relationship among environmental variables (vectors) and wetlands categorised according to dominant vegetation. Abbreviations: PM wetlands = permanent and multi-stratified wetlands, and PE wetlands = permanent and emergent wetlands.

since some small studied lakes also had a great number of mollusc species. Oertli et al. (2002) did not observe the relationships between wetland area and Sphaeriidae richness.

The macroinvertebrate richness usually declines from low to high altitudes, although this pattern can be blurred from lowlands to midlands (ca. $500 \mathrm{~m}$ ) (Stoneburner, 1977; Miserendino, 2001; Jacobsen, 2004). Oertli et al. (2002) regarded altitude as an important richness predictor to some macroinvertebrate families in Swiss ponds. While Stenert and Maltchik (2007) did not observe a negative relationship between altitude and macroinvertebrate richness in southern Brazil wetlands, Panatta et al. (2007) showed that the richness of Chironomidae was negatively associated with wetland altitude in this region. Our study showed that the mollusc richness was negatively associated with altitude. The lower richness of molluscs observed in high altitudes may be related with a low capacity of some species to tolerate extreme environmental and climatic conditions (see Hausdorf, 2006). Biomphalaria, Drepanotrema and Lymnaea columella were more frequent in the studied wetlands located at higher altitudes. The pulmonate genera have a strong ability to support harsh conditions (Brown, 2001). Sturm (2007) also observed a higher occurrence of Planorbidae species and other generalist molluscs in lakes of high altitude in the Eastern Alps. The biology of the amphibious gastropod Omalonyx convexus is poorly known, making 
it difficult to explain its association with wetlands of high altitude.

Several studies suggested that the hydroperiod influences the structure of wetland macroinvertebrate communities (Wellborn et al., 1996; Zimmer et al., 2000). Our study showed that the mollusc richness and composition were similar both in permanent and intermittent wetlands. The majority of the genera observed (pulmonate gastropods) are able to deal with long term hypoxia (Brown, 2001). The aestivation process was observed in several species of Biomphalaria, Drepanotrema and Lymnaea columella, including B. tenagophila (Teles and Marques, 1989) in Brazil. Many bivalve populations are restricted to shallow waters and susceptible to droughts or dry periods. However, the bivalves observed were represented exclusively by Sphaeriidae, a family with high tolerance to air exposure (McMahon and Bogan, 2001).

Water conductivity is closely associated with diversity and richness of aquatic invertebrates (Friday, 1987; Nyman et al., 2005). Lewis and Magnuson (2000) and Metzeling et al. (2006) found strong relationships between mollusc richness and electrical conductivity. Our results did not show any association between water conductivity and mollusc richness. Many studies have shown that this relationship is not a consensus regarding wetland systems. Horsák (2006) remarked that the snail richness did not increase with electrical conductivity. Several studies with Pisidium and Lymnaea columella have found different results in relation to the association between mollusc richness and water conductivity (Marchese and Drago, 1992; Berezina, 2003; Kazibwe et al., 2006; Horsák, 2006; Sturm, 2007). Our results showed that Biomphalaria and Ancylidae were mainly observed in wetlands with lower water conductivity. Berezina (2003) observed that Lymnaea columella is usually more tolerant to low values of salinity, and Kazibwe et al. (2006) sustained that Biomphalaria tend to avoid waters with high conductivity. Pisidium was registered preferentially in areas with high electrical conductivity in South America (Marchese and Drago, 1992).

The mollusc richness did not differ significantly between aquatic bed and emergent wetlands in the studied wetlands; however, the composition was different between them. The majority of the taxa observed showed previously some relationship with aquatic plants (Pereira et al., 2000a,b; Kotzian and Simões, 2006). Pomacea canaliculata and Ancylidae are commonly associated with macrophytes in southern Brazilian. Macrophytes function as substrate, food, local for eggs deposition and probably shelter for both taxa (Alexander and Covich, 1991; Veitenheimer-Mendes et al., 1992; Brown, 2001; Pizani et al., 2005; Damborenea, Brusa and Paola, 2006; Boland et al., 2008). Pisidium and Eupera have also been associated with Eichhornia (Mansur and VeitenheimerMendes, 1975; Ituarte and Dreher-Mansur, 1993; Ituarte, 1994). Lymnaea columella (algarivous) is commonly found associated with emergent vegetation (Pereira et al., 2000a), where periphyton can grow. Omalonyx convexus
(Barker, 2001) (herbivore) inhabits emergent vegetation and has been commonly found near the margins of many aquatic environments (Thomé et al., 2006).

Our results showed that the wetlands in southern Brazil are important habitats for molluscs, and that the richness and the composition of molluscs are associated with area, altitude, water conductivity and dominant vegetation. In terms of conservation, a wetland does not necessarily have to be large and located in lower altitudes to have a high value. In this study, smaller wetlands at high altitudes supported a mollusc composition that differed from those of larger wetlands and located in lower altitudes. In this sense, there is a need to promote conservation of all wetland systems in southern Brazil, regardless of their area, altitude and kind of dominant vegetation. These points should be seen as important to determine the environmental factors that shape and maintain biodiversity in these ecosystems. Such information is essential to develop conservation and management programs for wetlands in this region, where more than $90 \%$ of the wetland systems have already been lost, and the remaining ones are still at high risk due to the expansion of rice production and exotic Eucalyptus and pine plantations.

Acknowledgements - This research was supported by funds from UNISINOS (02.00.023/00-0) and CNPq (52370695.2). Leonardo Maltchik holds a Brazilian Research Council (CNPq) Research Productivity grant. We thank two anonymous reviewers for helpful comments on the manuscript. We declare that the data collection complied with Brazilian current laws.

\section{References}

AGUDO-PADRÓN, AI. and OLIVEIRA, JV., 2008. Malacological fauna in irrigated rice fields of the Southern Brazil: a comprehensive general study. UNITAS Malacologica, vol. 26, p. 8.

AHO, J., 1978. Freshwater snail populations and the theory of island biogeography. I A case study in southern Finland. Annales Zoologici Fennici, vol. 15, p. 146-154.

ALEXANDER, JE. and COVICH, AP., 1991. Predation risk and avoidance behavior in two freshwater snails. Biological Bulletin, vol. 180, p. 387-393

American Public Health Association - APHA, 1989. Standart methods for examination of water and wastewater. Washington: American Water Works Association, and Water Control Federation.

BACHMANN, A., 1960. Apuntes para una hidrobiología argentina II Ampullaria insularum Orb. y A. canaliculata Lam. (Moll. Prosobr., Ampullaridae). Observaciones biológicas y ecológicas. Acta do Primer Congreso Sudamericano de Zoología, vol. 1, p. 19-26.

BARKER, GM., 2001. Gastropods on land: phylogeny, diversity and adaptative morphology. In BARKER, GM. (Ed.). The biology of terrestrial mollusks. New York: CABI Publishing. p. 1-146.

BATZER, DP., DIETZ-BRANTLEY, SE., TAYLOR, BE. and DEBIASE, AE., 2004. Evaluating regional differences in macroinvertebrate communities from forested depressional 
wetlands across eastern and central North America. J. North American Benthological Society, vol. 24, no. 2, p. 403-414.

BEREZINA, NA., 2003. Tolerance of freshwater invertebrates to changes in water salinity. Russian Journal of Ecology, vol. 34, no. 4, p. 261-266.

BOLAND, BA., MEERHOFF, M., FOSALBA, C., MAZZEO, N., BARNES, MA. and BURKS, R., 2008. Juvenile snails, adult appetites: contrasting resource consumption between two species of applesnails (Pomacea). Journal of Molluscan Studies, vol. 74 , no. 1 , p. $47-54$

BONETTO, AA., BECHARA, JA. and TASSARA, MP., 1982. Los moluscos de la família Planorbidae en el area del rio Paraná medio. Physis, vol. 41, no. 100, p. 1-6.

BRÖNMARK, C., 1985. Freshwater snail diversity: effects of pond area, habitat heterogeneity and isolation. Oecologia, vol. 67 , no. 1 , p. $127-131$

BROWN, MK., 2001. Mollusca: Gastropoda. In THORP, JH. and COVICH, AP. (Eds.). Ecology and classification of North American Freshwater Invertebrates. San Diego: Academic Press. p. 297-329.

CHIEFFI, PP. and MORETTI, IG., 1979. Flutuação mensal na densidade de populações malacológicas em criadouro natural do município de Londrina, Estado do Paraná, Brasil. Revista do Instituto Adolfo Lutz, vol. 39, no. 1, p. 45-50.

COIMBRA, HS., SCHUCH, LFD., VEITENHEIMERMENDES, IL. and MEIRELES, MCA., 2005. Neorickettsia (Ehrlichia) risticii no sul do Brasil: Heleobia spp. (Mollusca: Hidrobiidae) e Parapleurolophocecous cercariae (Trematoda: Digenea) como possíveis vetores. Arquivos do Instituto Biológico, vol. 72, no. 3, p. 325-329.

CUMMINS, KS. and BOGAN, AE., 2006. Unionoida: freshwater mussels. In (STURM, CF., PEARCE, TA. and VALDÉS, A. (Eds.). The mollusks: a guide to their study, collection, and preservation. Pittsburgh: American Malacological Society. p. 313-326.

DAMBORENEA, C., BRUSA, F. and PAOLA, A., 2006. Variation in worm assemblages associated with Pomacea canaliculata (Caenogastropoda: Ampullariidae) in sites near the Río da Plata estuary, Argentina. Biocell, vol. 30, no. 3, p. $457-468$.

DARRIGRAN, G., 2002. Potential impact of filter-feeding invaders on temperate inland freshwater environments. Biological Invasions, vol. 4, no. 1-2, p. 145-156.

DILLON Jr., RT., 2000. The Ecology of fresh water Mollusca. Cambridge: University Press.

FAGUNDES, CK., BEHR, ER. and KOTZIAN, CB., 2008. Diet of Iheringichthys labrosus (Siluriformes, Pimelodidae) in Ibicuí River, Southern Brazil. Iheringia, Série Zoologia, vol. 98, no. 1, p. 1-6.

FRIDAY, LE., 1987. The diversity of macroinvertebrate and macrophyte communities in ponds. Freshwater Biology, vol. 18, no. 1, p. $87-104$.

GARCIA, A., HOEINGHAUS, DJ., VIEIRA, JP., WINEMILLER, KO., MOTTA-MARQUES, DML. and BEMVENUTI, MA., 2006. Preliminary examination of food web structure of Nicola Lake (Taim hydrological system, south Brazil) using dual $\mathrm{C}$ and $\mathrm{N}$ stable isotope analysis. Neotropical Ichthyology, vol. 4, no. 2, p. 279-284.
GÉRARD, C., 2001. Consequences of drought on freshwater gastropod and trematode communities. Hydrobiology, vol. 459, no. 1, p. $9-18$.

GOMES, ADS. and MAGALHÃES Jr., AMD., 2004. Arroz. irrigado no Sul do Brasil. Pelotas: EMBRAPA.

HALL, DL., WILLIG, MR., MOORHEAD, DL., SITES, RW., FISH, EB. and MOLLHAGEN, TR., 2004. Aquatic macroinvertebrate diversity of playa wetlands: the role of landscape and island biogeography characteristics. Wetlands, vol. 24 , no. 1 , p. 77-91

HAUSDORF, B., 2006. Latitudinal and altitudinal diversity patterns and Rapoport effects in north-west European land snails and their causes. Biological Journal of the Linnean Society, vol. 87, no. 2, p. 309-323.

HAUSMAN, A., 1995. Províncias hidrogeológicas do estado do Rio Grande do Sul - RS. Acta Geologica Leopoldensia, vol. 2, p. 1-127. (série mapas).

HEINO, J., 2000. Lentic macroinvertebrate assemblage structure along gradients in spatial heterogeneity, habitat size and water chemistry. Hydrobiologia, vol. 418, no. 1, p. 229-242.

HEINO, J. and MUOTKA, T., 2006. Landscape positiom, local environmental factors, and the structure of molluscan assemblages of lakes. Landscape Ecology, vol. 21, no. 4, p. $499-507$

HORSÁK, M., 2006. Mollusc community patterns and species response curves along a mineral richness gradient: a case study in fens. Journal of Biogeography, vol. 33, no. 1, p. 98-107.

HORSÁK, M., HÁJEK, M., DÍTE, D. and TICHÝ, L. 2007. Modern distribution patterns of snails and plants in the western Carpathian spring fens: is it a result of historical development? Journal of Molluscan Studies, vol. 73, no. 1, p. 53-60.

ITUARTE, CF., 1994. Eupera guaraniana n. sp. (Pelecypoda: Sphaeriidae) del Río Uruguay, Argentina. Gayana Zoologia, vol. 58 , no. 1 , p. 1-7.

ITUARTE, CF. and DREHER-MANSUR, MC., 1993. Eupera elliptica n. sp., una nueva especie en Río Iguazú, Misiones, Argentina. Neotrópica, vol. 39, no. 1, p. 11-16.

JACOBSEN, D., 2004. Contrasting patterns in local and zonal family richness of stream invertebrates along and Andean altitudinal gradient. Freshwater Biology, vol. 49, no. 10, p. 1293-1305.

JUNK, WJ. and ROBERTSON, BA., 1997. Aquatic invertebrates. In JUNK, W. (Eds.). The Central Amazon floodplain: ecology of a pulsing system. Berlin: Springer-Verlag. p. 279-298. (Ecological Studies, no. 126).

KAZIBWE, F., MAKANGA, B., RUBAIRE-AKIIKI, C., OUMA, J., KARIUKI, C., KABATEREINE, NB., BOOTH, M., VENNERVALD, BJ., STURROCK, RF. and STOTHARD, JR., 2006. Ecology of Biomphalaria (Gastropoda: Planorbidae) in Lake Albert, Western Uganda: snail distributions, infection with schistosomes and temporal associations with environmental dynamics. Hydrobiologia, vol. 568, no. 1, p. 433-444.

KLOOS, H., PASSOS, LKJ., LOVERDE, P., OLIVEIRA, RC. and GAZZINELLI, A., 2004. Distribution and Schistosoma mansoni infection of Biomphalaria glabrata in different habitats in a rural area in the Jequitinhonha Valley, Minas Gerais, Brazil: environmental and epidemiological aspects. Memórias do Instituto Oswaldo Cruz, vol. 99, no. 7, p. 673-681. 
KOTZIAN, CB. and SIMÕES, MG., 2006. Taphonomy of Recent freshwater molluscan death assemblages, Touro Passo Stream, Southern Brazil. Revista Brasileira de Paleontologia, vol. 9, no. 2, p. 243-260.

KRETZSCHMAR, AU. and HECKMAN, CW., 1995. Estratégias de sobrevivência das espécies de Ampullaridae (Mollusca, Gastropoda) durante mudanças das condições ambientais extremas do ciclo sazonal sob o clima tropical úmido e seco. Acta Limnologica Brasiliensia, vol. 7, no. 1, p. 60-66.

LASSEN, HH., 1975. The diversity of freshwater snails in view of the equilibrium theory of island biogeography. Oecologia, vol. 19 , no. 1 , p. 1-8.

LEWIS, DB. and MAGNUSSON, JJ., 2000. Landscape spatial patterns in freshwater snail assemblages across Northern Highland catchments. Freshwater Biology, vol. 43, no. 3, p. $409-420$.

MALTCHIK, L., 2003. Three new wetlands inventories in Brazil. Interciencia, vol. 28, no. 7, p. 421-423.

MALTCHIK, L., ROLON, AS., GUADAGNIN, DL. and STENERT, C., 2004. Wetlands of Rio Grande do Sul, Brazil: a classification with emphasis on their plant communities. Acta Limnologica Brasiliensia, vol. 16, no. 2, p. 137-151.

MANSUR, MC. and VEITENHEIMER, IL., 1975. Nova espécie de Eupera (Bivalvia: Sphaeriidae) e primeiros estudos anatômicos dentro gênero. Iheringia, Série Zoologia, vol. 47, p. 23-46.

MANSUR, MCD. and PEREIRA, D., 2006. Bivalves límnicos da bacia do rio dos Sinos, Rio Grande do Sul, Brasil (Bivalvia, Unionoida, Veneroida e Mytiloida). Revista Brasileira de Zoologia, vol. 23, no. 4, p. 1123-1147.

MARCHESE, M. and DRAGO, IE., 1992. Benthos of the lotic environments in the middle Paraná River system: transverse zonation. Hydrobiologia, vol. 237, no. 1, p. 1-13.

MCCUNE, B. and MEFFORD, MJ., 1999. PC-ORD: multivariate analysis of ecological data. Oregon: MjM Software Design.

MCMAHON, RF. and BOGAN, AE., 2001. Mollusca: Bivalvia. In THORP, JH. and COVICH, AP. (Eds.). Ecology and classification of North American Freshwater Invertebrates. San Diego: Academic Press. p. 331-429.

METZELING, L., PERRISS, SD. and DAVID, R., 2006. Can the detection of salinity and habitat simplification using rapid bioassessment of benthic invertebrates be improved through finer taxonomic resolution or alternative indices? Hydrobiologia, vol. 572 , no. 1 , p. 235-252.

MISERENDINO, ML., 2001. Macroinvertebrates assemblages in Andean Patagonian rivers and streams: environmental relationships. Hydrobiologia, vol. 444, no. 1-3, p. 147-158.

MITSCH, WJ. and GOSSELINK, JG., 2000. Wetlands. New York: John Wiley and Sons.

MOCHIDA, O., 1991. Spread of freshwater Pomacea snails (Mollusca: Piliidae) from Argentina to Asia. Micronesia, vol. 3, no. supl., p. 51-62.

NARANJO, LG., 1995. An evaluation of the first inventory of South American wetlands. Vegetatio, vol. 118, no. 1-2, p. 125-129.
NYMAN, M., KORHOLA, A. and BROOKS, SJ., 2005. The distribution and diversity of Chironomidae (Insecta: Diptera) in western Finnish Lapland, with special emphasis on shallow lakes. Global Ecology and Biogeography, vol. 14, no. 2, p. 137-153.

NEIFF, JJ., 2001. Diversity in some tropical wetland systems of South America. In GOPAL, B., JUNK, WJ. and DAVIES, JA. (Eds.). Biodiversity in wetlands: assessment, function and conservation. Leinden: Backhuys Publishers. p. 157-186.

NEIFF, AP. and NEIFF, JJ., 2006. Riqueza de especies y similaridad de los invertebrados que viven en plantas flotantes de la planicie de inundación del Río Paraná (Argentina). Interciencia, vol. 31, no. 3, p. 220-225.

OERTLI, B., JOYE, DA., CASTELlA, E., JUGE, R., CAMBIN, D. and LACHAVANNE, J., 2002. Does size matter? The relationship between pond area and biodiversity. Biological Conservation, vol. 104, no. 1, p. 59-70.

PANATTA, Á., STENERT, C., FREITAS, SMF. and MALTCHIK, L., 2006. Diversity of chironomid larvae in palustrine wetlands of the Coastal Plain in the South of Brazil. Limnology, vol. 7, no. 1, p. 23-30.

PANATTA, Á., STENERT, C., SANTOS, EM. and MALTCHIK, L., 2007. Diversity and distribution of Chironomid larvae in wetlands is southern Brazil. Journal of the Kansas Entomological Society, vol. 80, no. 3, p. 229-242.

PEREIRA, D., VEITENHEIMER-MENDES, IL., MANSUR, MCD. and SILVA, MCP., 2000a. Malacofauna límnica do sistema de irrigação da microbacia do arroio Capivara, Triunfo, RS, Brasil. Biociências, vol. 8, no. 1, p. 137-157.

PEREIRA, D., KONRAD, HG. and PALOSKI, NN., 2000b. Gastrópodos límnicos da bacia do Rio Camaquã, RS, Brasil. Acta Biologica Leopoldensia, vol. 22, no. 1, p. 55-66.

PEREIRA, D., INDA, LA., CONSONI, JM. and KONRAD, HG., 2001. Composição e abundância de espécies de moluscos do bentos marginal da microbacia do arroio Capivara, Triunfo, RS, Brasil. Biociências, vol. 9, no. 1, p. 3-20.

PIZANI, N.,ESTEBENET,AL. and MARTÍN, PR., 2005. Effects of submersion and aerial exposure on clutches and hatchlings of Pomacea canaliculata (Gastropoda: Ampulariidae). American Malacological Bulletin, vol. 20, no. 1, p. 55-63.

RADAMBRASIL, 1986. Levantamento de recursos naturais. Rio de Janeiro: IBGE.

RAMBO, B., 2000. A fisionomia do Rio Grande do Sul: ensaio de monografia natural. São Leopoldo: UNISINOS.

SANDERSON, RA., EYRE, MD. and RUSHTON, SP., 2005. Distribution of selected macroinvertebrates in a mosaic of temporary and permanent freshwater ponds as explained by autologistic models. Ecography, vol. 28, no. 3, p. 355-362.

SHINE, C. and KLEMM, C. 1999. Wetlands, water and the law: using law to advance wetland conservation and wide use. Gland: IUCN.

SIMONE, LRL., 2006. Land and freshwater molluscs of Brazil: an illustrated inventory on the Brazilian malacofauna, including neighbour regions of the South America, respect to the terrestrial and freshwater ecosystems. São Paulo: FAPESP.

SPENCER, M., BLAUSTEIN, L., SCHWARTZ, SS. and COHEN, JE., 1999. Species richness and proportion of predatory 
animal species in temporary freshwater pools; relationships with habitat size and permanence. Ecology Letters, vol. 2, no. 3, p. 157-166.

STENERT, C. and MALTCHIK, L. 2007. Influence of area, altitude and hydroperiod on macroinvertebrate communities in southern Brazil wetlands. Marine Freshwater Research, vol. 58, no. 11 , p. $993-1001$.

STENERT, C., BACCA, RC., MOSTARDEIRO, CC. and MALTCHIK, L., 2008. Environmental predictors of macroinvertebrate communities in coastal wetlands of southern Brazil. Marine Freshwater Research, vol. 59, no. 6, p. $540-548$.

STONEBURNER, DL., 1977. Preliminary observations of the aquatic insects of the Smoky Mountains: altitudinal zonation in the spring. Hydrobiologia, vol. 56, no. 2, p. 137-143.

STUDINSKI, JM. and GRUBBS, SA., 2007. Environmental factors affecting the distribution of aquatic invertebrates in temporary ponds in Mammoth Cave National Park, Kentucky, USA., vol. 575, no. 1, p. 211-220.

STURM, R., 2007. Freshwater molluscs in mountain lakes in Eastern Alps (Austria): relationship between environmental variables and lake colonization. Journal of Limnology, vol. 66, no. 2, p. 160-169.

TARR, TL., BABER, MJ. and BABBITT, KJ., 2005. Macroinvertebrate community structure across a wetland hydroperiod gradient in southern New Hampshire, USA. Wetlands Ecology and Management, vol. 13, no. 3, p. 321-334.

TELES, HMS. and MARQUES, CCA., 1989. Estivação de Biomphalaria tenagophila (Pulmonata, Planorbidae). Revista de Saúde Pública, vol. 23, no. 1, p. 76-78.
TER-BRAAK, CJF., 1986. Canonical correspondence analysis: a new eigen-vector technique for multivariate direct gradient analysis. Ecology, vol. 67, no. 6, p. 1167-1179.

TER-BRAAK, CJF. and ŠMILAUER, P., 1998. CANOCO Reference Manual and User's Guide to CANOCO for Windows: Software for Canonical Community Ordination (version 4'). Ithaca: Microcomputer Power.

THOMÉ, JW., GOMES, SR. and PICANÇO, JB., 2006. Guia ilustrado: os caracóis e as lesmas dos nossos bosques e jardins. Pelotas: USEB.

VEITENHEIMER-MENDES,IL.,LOPES-PITONI,VL.,SILVA, MCP., ALMEIDA-CAON, JE. and SCHRÖDER-PFEIFER, NT., 1992. Moluscos (Gastropoda e Bivalvia) ocorrentes nas nascentes do rio Gravataí, rio Grande do Sul, Brasil. Iheringia, Série Zoologia, vol. 82, no. 73, p. 69-76.

WELLBORN, GA., SKELLY, DK. and WERNER, EE., 1996. Mechanisms creating community structure across a freshwater habitat gradient. Annual Review of Ecology and Systematics, vol. 27, p. 337-363.

WHILES, MR. and GOLDWITZ, BS., 2005. Macroinvertebrate communities in Central Plate River wetlands: patterns across a hydrologic gradient. Wetlands, vol. 25, no. 2, p. 462-472.

ZIMMER, KD., HANSON, MA., and BUTLER, MG., 2000. Factors influencing invertebrate communities in prairie wetlands: a multivariate approach. Canadian Journal of Fisheries and Aquatic Sciences, vol. 57, no. 1, p. 76-85. 